\title{
Evaluation and Optimization of a Serum-based Minimum Inhibitory Concentration Assay to Caspofungin in Candida albicans Clinical Isolates
}

\author{
Young Bin Yoo ${ }^{1}$, Sung-Soon Kim ${ }^{1}$, Young Kwon Kim ${ }^{1, \dagger}$ and Sunghyun Kim ${ }^{2, \dagger}$ \\ ${ }^{I}$ Department of Biomedical Laboratory Science, College of Medical Sciences, \\ Konyang University, Daejeon 35365l, Korea \\ ${ }^{2}$ Department of Clinical Laboratory Science, College of Health Sciences, \\ Catholic University of Pusan, Busan 46252, Korea
}

\begin{abstract}
In the present study, a serum-based minimum inhibitory concentration (MIC) testing to caspofungin was optimized and evaluated to solve the limitations of the conventional Clinical and Laboratory Standards Institute (CLSI) guideline-based antifungal agent MIC test and the usefulness of this testing for clinical application was determined. A total of 105 Candida albicans clinical isolates were used for measuring MIC to caspofungin. Results showed that growth characteristics were different according to types of serum and the mouse serum was the most suitable for this assay. In order to measure the optimal concentration of mouse serum, 0 to $100 \%$ mouse serum were added to the media during fungal culture. The optimal concentration of serum was $50 \%$ when consideration of antifungal agent administration and inoculum size, serum components and ease of hyphae separated, and the consideration of the degree of growth. In comparison of the usefulness between the conventional Alamar-modified broth microdilution MIC assay and 50\% mouse serum-based MIC testing, the range of $\mathrm{MIC}_{80}$ of the Alamar-modified broth microdilution MIC assay was $0.13 \sim 2.0 \mu \mathrm{g} / \mathrm{mL}$ (SD \pm 0.42 $\mu \mathrm{g} / \mathrm{mL}$ ) and that of the $50 \%$ mouse serum-based MIC assay was $2.0 \sim 32.0 \mu \mathrm{g} / \mathrm{mL}$ (SD $\pm 9.01 \mu \mathrm{g} / \mathrm{mL}$ ). The range of $\mathrm{MIC}_{50}$ of the Alamar-modified broth microdilution MIC assay was $0.13 \sim 2.0 \mu \mathrm{g} / \mathrm{mL}$ (SD $\pm 0.40 \mu \mathrm{g} / \mathrm{mL}$ ) and that of the $50 \%$ mouse serum-based MIC assay was $1.0 \sim 16.0 \mu \mathrm{g} / \mathrm{mL}$ (SD $\pm 2.36 \mu \mathrm{g} / \mathrm{mL}$ ). The MICs of $50 \%$ mouse serum-based MIC testing was increased by up to 4 to 64 times than Alamar-modified broth microdilution MIC assay. In conclusion, a $50 \%$ mouse serum-based MIC assay was more useful for measuring MIC in Candida albicans clinical isolates than conventional colorimetric broth microdilution MIC testing.
\end{abstract}

Key Words: Candida albicans, Minimum inhibitory concentration, Serum-based MIC assay, Caspofungin, Clinical isolates

\author{
서 론 \\ Candida albicans는 전체 진균혈증 원인의 약 $50 \sim 70 \%$
}

를 차지하며(Pfaller MA., 1996), 주로 인체 피부나 점막의 정상 상재균으로 존재하고 있고, 의료기관 내 입원환자 의 혈액뿐만 아니라 다양한 신체부위에서도 흔히 분리 된다고 알려져 있다(Shin JH et al., 1999). 칸디다혈증

\footnotetext{
* Received: September 27, 2016 / Revised: January 6, 2017 / Accepted: January 6, 2017

${ }^{\dagger}$ Corresponding author: Sunghyun Kim. Department of Clinical Laboratory Science, College of Health Sciences, Catholic University of Pusan, Busan 46252, Korea.

Tel: +82-51-510-0560, Fax:+82-51-510-0568, e-mail: shkim0423@cup.ac.kr

${ }^{\dagger}$ Corresponding author: Young Kwon Kim. Department of Biomedical Laboratory Science, College of Medical Sciences, Konyang University, Daejeon 35365 , Korea.

Tel: +82-42-660-6371, Fax:+82-42-543-6370, e-mail: ykkim3245@konyang.ac.kr

(C) The Korean Society for Biomedical Laboratory Sciences. All rights reserved.

(C) This is an Open Access article distributed under the terms of the Creative Commons Attribution Non-Commercial License (http://creativecommons.org/licenses/by-nc/3.0/) which permits unrestricted non-commercial use, distribution, and reproduction in any medium, provided the original work is properly cited.
} 
(candidemia)은 인체 피부 및 점막의 Candida 속 정상 상 재균 무리가 혈류(bloodstream) 내로 유입되거나 혹은 오 염된 수액, 의료기기, 의료진 등 오염된 병원환경으로부 터 다양한 경로를 통해 혈류로 유입되어 일어나게 된다 (Pfaller MA., 1996).

다양한 항진균제(antifungal agents) 중 Echinocandin계는 세포벽의 주요 구조인 $\beta$-1,3-glucan의 합성을 억제하며, 대 표적으로 caspofungin이 임상에서 가장 많이 사용되고 있 고, 그 외에도 anidulafungin, micofungin 등이 포함된다 (Kanafani ZA et al., 2008).

최근 항진균제의 사용이 증가함에 따라 1990년대 이전 에는 매우 드물게 나타나던 항진균제에 대한 내성율이 증가하고 있어 매우 중요한 문제로 대두되고 있는 실정 이다(White TC et al., 1998). Candida 감염에는 치료와 예방 이 우수하다고 알려진 Echinocandin계 항진균제인 caspofungin과 Azole계 항진균제인 fluconazole이 자주 사용됨에 따라 칸디다증(Candidiasis)에서 이 항진균제들에 대한 내 성 또한 문제가 되고 있다(Pfaller MA et al., 1997). 진균 감염증의 치료를 위해서는 항진균제의 적용이 일반적이나, 현재 임상에서는 지속적인 발열을 동반하는 호중구감소 증(neutropenia) 환자, 항암화학요법(chemotherapy)을 받고 있는 백혈병환자, 저체중신생아 등 면역력이 저하된 환자 들에 대해서는 항진균제 사용 농도를 의사의 경험적 치료 에 의존하고 있는 실정이다(Healy et al., 2005; Walsh TJ et al., 2004). 이러한 경험적 항진균제 투여는 발열, 오한, 저 혈압, 오심, 구토 등의 이상반응 발생률을 높일 위험이 높 으며, 장기간 투여 시 신장 독성과 같은 부작용 문제가 증가되어 임상 현장에서 효과적인 항진균제의 선택 및 정 확한 투여량 결정을 위해서는 빠르고 정확한 항진균제 감수성 검사가 요구된다.

현재 표준화된 항진균제 MIC 측정법으로는 Clinical and Laboratory Standards Institute (CLSI) 가이드라인을 이 용한 방법, E-test, 디스크 확산법, 유세포 분석기를 사용 하는 방법, 세포 내 Ergosterol 측정법 등과 같이 생체 외 (in vitro) 반응을 기반으로 한 검사들이 사용되고 있으나 (Rex JH et al., 2001), 이 검사법들은 생체 외와 생체 내(in vivo)에서의 반응에 관한 연관성을 확인할 수 없기 때문 에 그 분석 결과에 따른 임상에서의 적용이 매우 어려운 실정이다.

따라서, 본 연구에서는 총 105 주의 C. albicans 임상분리 균주를 대상으로 serum-based MIC 측정법의 각 조건에 따른 결과를 기존의 CLSI 가이드라인을 변형한 Alamar-

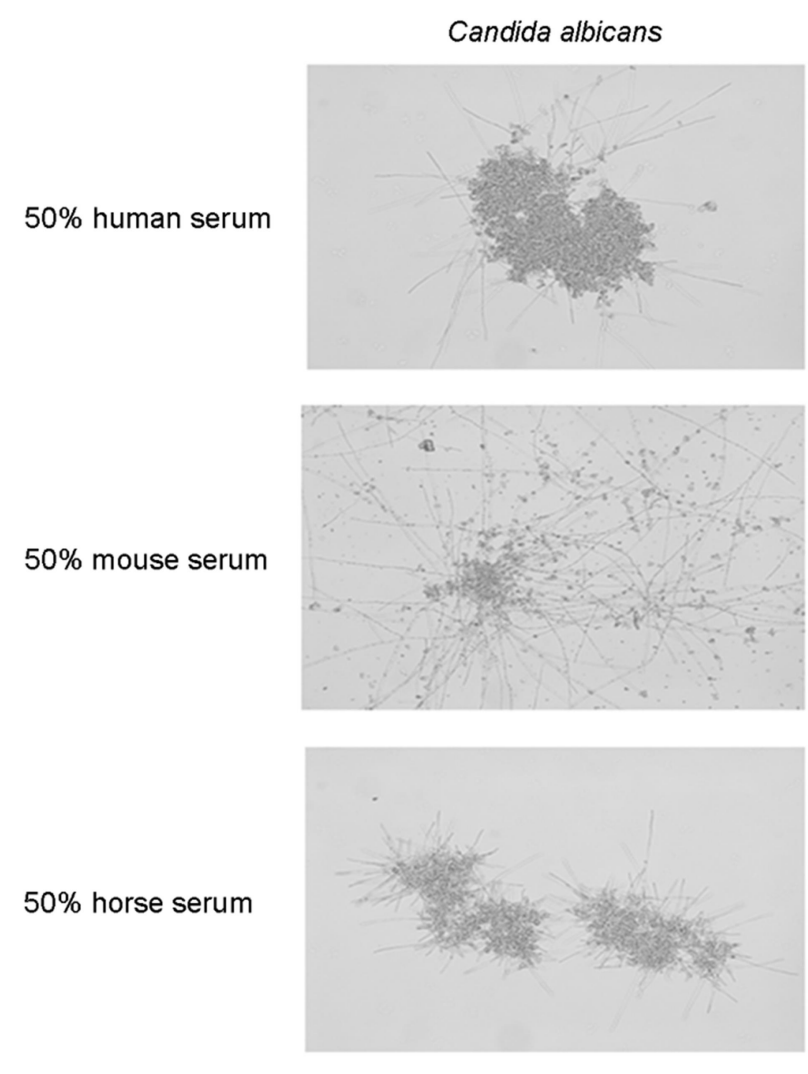

Fig. 1. Culture characteristics of C. albicans according to types of serum.

modified broth microdilution법에 의한 MIC 측정치와 비 교하였고, 그 유용성을 평가하여 기존 검사법의 제한점 극복 가능성 여부 및 임상적용 가능성을 확인하고자 하 였다.

\section{재료 및 방법}

\section{임상분리균주(Clinical isolates)}

한국의진균자원은행(Korean Culture Collection of Medical Fungi, KCMF)에 기탁되어 있는 105 주의 C. albicans 임상 분리균주와 1 주의 C. albicans ATCC 10231 표준균주를 분 양 받아 본 연구에 사용하였다. 총 105 주의 C. albicans 임 상분리균주는 혈액검체 유래 52건, 소변검체 유래 9건, 객 담검체 유래 9건, 피부검체 유래 7건, 체액검체 유래 4건, 카테터 유래 3 건, 농(pus)검체 유래 1건, 기타 검체 유래 20건이 포함되어 있다. 


\section{Alamar-modified broth microdilution법을 이용한 cas- pofungin에 대한 MIC 측정}

C. albicans 임상분리균주의 MIC 측정은 변형된 CLSI 가이드라인 M27-A3에 따라 진행하였다(Rex P et al., 2008; Tiballi RN et al., 1995). 항진균제인 caspofungin (Merck, USA)은 Dimethyl sulfoxide (DMSO)에 녹여 최종 $3 \mathrm{mg} / \mathrm{mL}$ 의 농도로 만들었고, 연속 배수로 희석하여 최종농도의 범위가 $0.003 \sim 2 \mu \mathrm{g} / \mathrm{mL}$ 가 되도록 하였다. C. albicans 균주 를 Sabouraud dextrose agar (SDA) 평판배지에 접종 후 $35^{\circ} \mathrm{C}$ 에서 24 시간 동안 배양한 후 세 개 정도의 집락을 취한 후 $0.85 \%$ 식염수에 균을 현탁한 후 u-bottom shaped 96-well plate를 이용해 $530 \mathrm{~nm}$ 에서 흡광도를 측정하였고, 균주는 적정 흡광도 값인 $0.9 \sim 1.07\left(1.5 \times 10^{7} \sim 2.0 \times\right.$ $10^{7} \mathrm{cell} / \mathrm{mL}$ )에 맞추어 준비하였다. 준비된 균 혼탁액을 RPMI-MOPS 배지를 이용해 1/10 1/100로 단계 희석한 후 균 혼탁액의 1/4에 해당하는 양의 Alamar blue (Serotec $\mathrm{Ltd}, \mathrm{USA})$ 를 첨가하고 잘 섞은 후 $125 \mu \mathrm{L}$ 씩 각 well에 분주하였다. 성장 대조군은 동일하게 $125 \mu \mathrm{L}$ 의 균 혼탁 액을 분주하였고, 배지 대조군에는 균 혼탁액 첨가 없이
RPMI 배지에 $1 / 4$ 의 Alamar blue만을 섞은 후 분주하였다. 균 접종 후 $35^{\circ} \mathrm{C}$ 에서 24 시간 동안 배양하였다. 결과판 정은 분광광도계(spectrophotometer)를 이용해 $570 \mathrm{~nm}$ 와 $600 \mathrm{~nm}$ 에서 흡광도를 측정하였다.

\section{Serum-based 항진균제 감수성 검사법을 이용한 cas- pofungin에 대한 MIC 측정}

RPMI 배지에 human serum (human male, type AB: Sigma, Hungary), mouse serum (Equitech-Bio, USA), horse serum (Gibco, New Zealand)을 농도 별로 각각 첨가하여 서로 다른 시험군을 만들어 사용하였고, 2x Ferric ammonium citrate (Sigma, USA) 배지를 준비해 모든 well에 $100 \mu \mathrm{L}$ 씩 분주하였다. 항진균제인 caspofungin은 $\mathrm{DMSO}$ 에 녹여 최 종 $3 \mathrm{mg} / \mathrm{mL}$ 의 농도로 만들었고, 연속 배수로 희석하여 최종농도의 범위가 $0.06 \sim 32 \mu \mathrm{g} / \mathrm{mL}$ 이 되도록 하였다. $C$. albicans 균주를 $\mathrm{SDA}$ 평판배지에 접종 후 $35^{\circ} \mathrm{C}$ 에서 24 시간 동안 배양한 후 세 개 정도의 집락을 취해 $0.85 \%$ 식염수에 균을 현탁한 후 u-bottom shaped 96-well plate를 이용해 $530 \mathrm{~nm}$ 에서 흡광도를 측정하였고, 균주는 적정 흡 광도 값인 $0.9 \sim 1.07\left(1.5 \times 10^{7} \sim 2.0 \times 10^{7} \mathrm{cel} / \mathrm{mL}\right)$ 에 맞
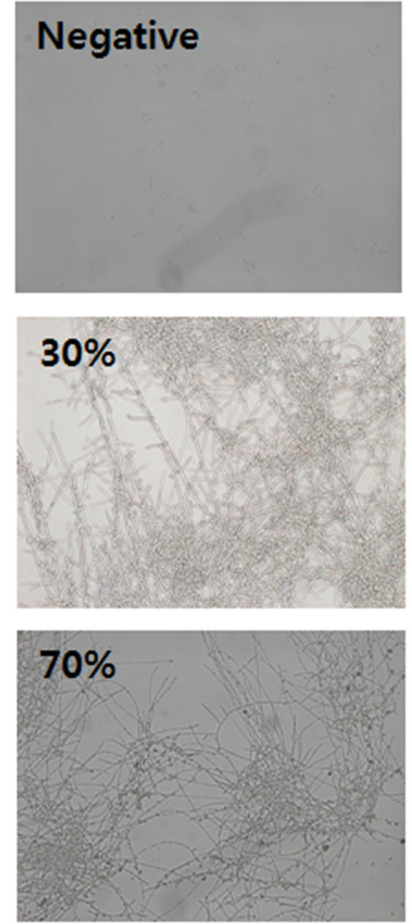
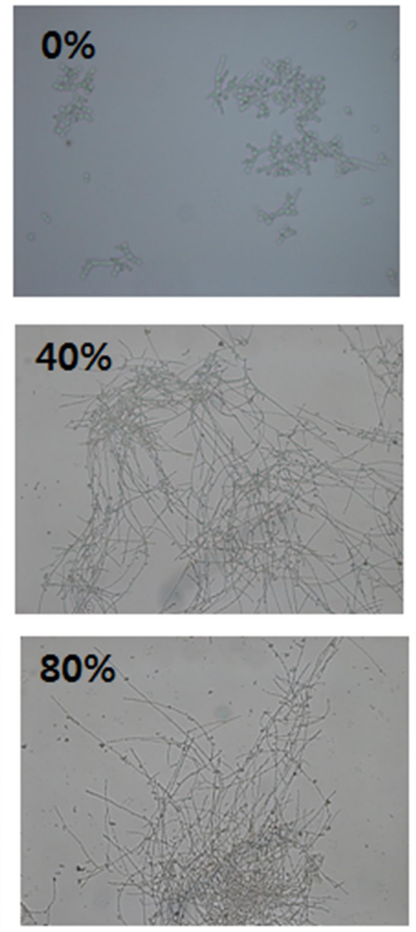
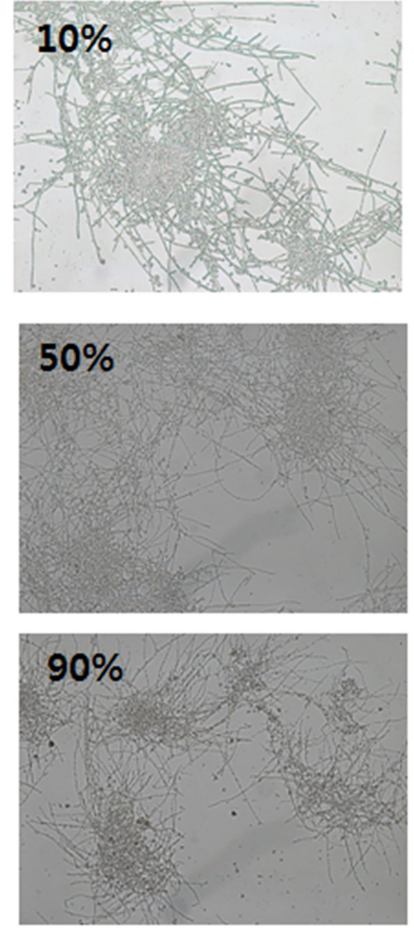
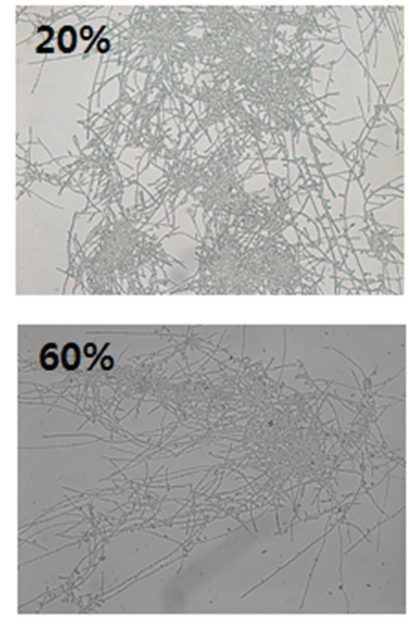

$100 \%$

Fig. 2. Culture characteristics of $C$. albicans according to the amount of mouse serum. 
추어 준비하였다. 준비된 균 혼탁액을 $2 \mathrm{x} \mathrm{Fe}$ 배지를 이용 해 $1 / 500$ 로 희석한 후 $50 \mu \mathrm{L}$ 씩 각 well에 분주하였다. 성 장 대조군은 동일하게 $50 \mu \mathrm{L}$ 의 균 혼탁액을 분주하였고, 배지 대조군에는 균 혼탁액 첨가 없이 $2 \mathrm{x} \mathrm{Fe}$ 배지를 분주 하였다. 균 접종 후 $35^{\circ} \mathrm{C}$ 에서 24 시간 동안 배양하였다. 결과판정을 위해 inverted type microscopy를 이용해 각 well을 사진 촬영하였다. 최고 농도의 항진균제가 들어있 는 well부터 성장 대조군과 동일하게 균이 자란 well까지 모두 관찰하였고, 균이 자라지 않은 well의 농도를 계산 하여 S-MIC로 판정하였다.

\section{결 과}

\section{혈청 종류에 따른 C. albicans의 생장 특성}

혈청 종류에 따른 C. albicans의 생장 특성 및 효과를 분석하기 위해 배양 시 human, mouse, horse 유래의 혈청 을 각각 첨가하여 그 효과를 분석한 결과, 사용한 혈청의 종류에 따라 C. albicans의 생장 특성이 달라지는 것을 확 인할 수 있었다.

$50 \%$ human 혈청을 사용한 경우, caspofungin을 처리하
지 않은 대조군에서 가성균사(pseudohyphae)가 방사형으 로 뭉쳐 자라는 형태를 보이면서 정상적으로 생육하는 것 을 관찰할 수 있었다. Caspofungin을 처리한 경우, 세포벽 합성 억제 효과로 인해 균사가 뭉쳐 자라서 정확한 $\mathrm{MIC}$ 측정이 힘들다는 것을 확인할 수 있었다. 하지만, $50 \%$ mouse 혈청을 사용한 경우, caspofungin을 처리하지 않은 대조군에서 전형적인 가성균사가 실처럼 길게 뻗어 자라 는 것을 확인할 수 있었으며 caspofungin을 처리한 경우에 도 항진균제에 의한 생육 억제 효과가 가장 뚜렷하게 나 타나 $\mathrm{MIC}$ 측정에 용이함을 알 수 있었다. $50 \%$ horse 혈청 을 사용한 경우, caspofungin을 처리하지 않은 대조군에서 균사가 뭉쳐서 자라는 형태를 보였으며, caspofungin 처리 시에도 human 혈청을 첨가 했을 때와 마찬가지로 균사가 뭉쳐 자라 정확한 $\mathrm{MIC}$ 측정이 어려움을 관찰할 수 있었 다(Fig. 1)

\section{최적 혈청 첨가 농도 분석}

혈청 종류에 따른 C. albicans의 생장 특성 관찰 결과 $50 \%$ mouse 혈청을 사용하였을 경우 가성균사의 뚜렷한 관찰이 가능하였고, caspofungin을 처리하였을 경우에도

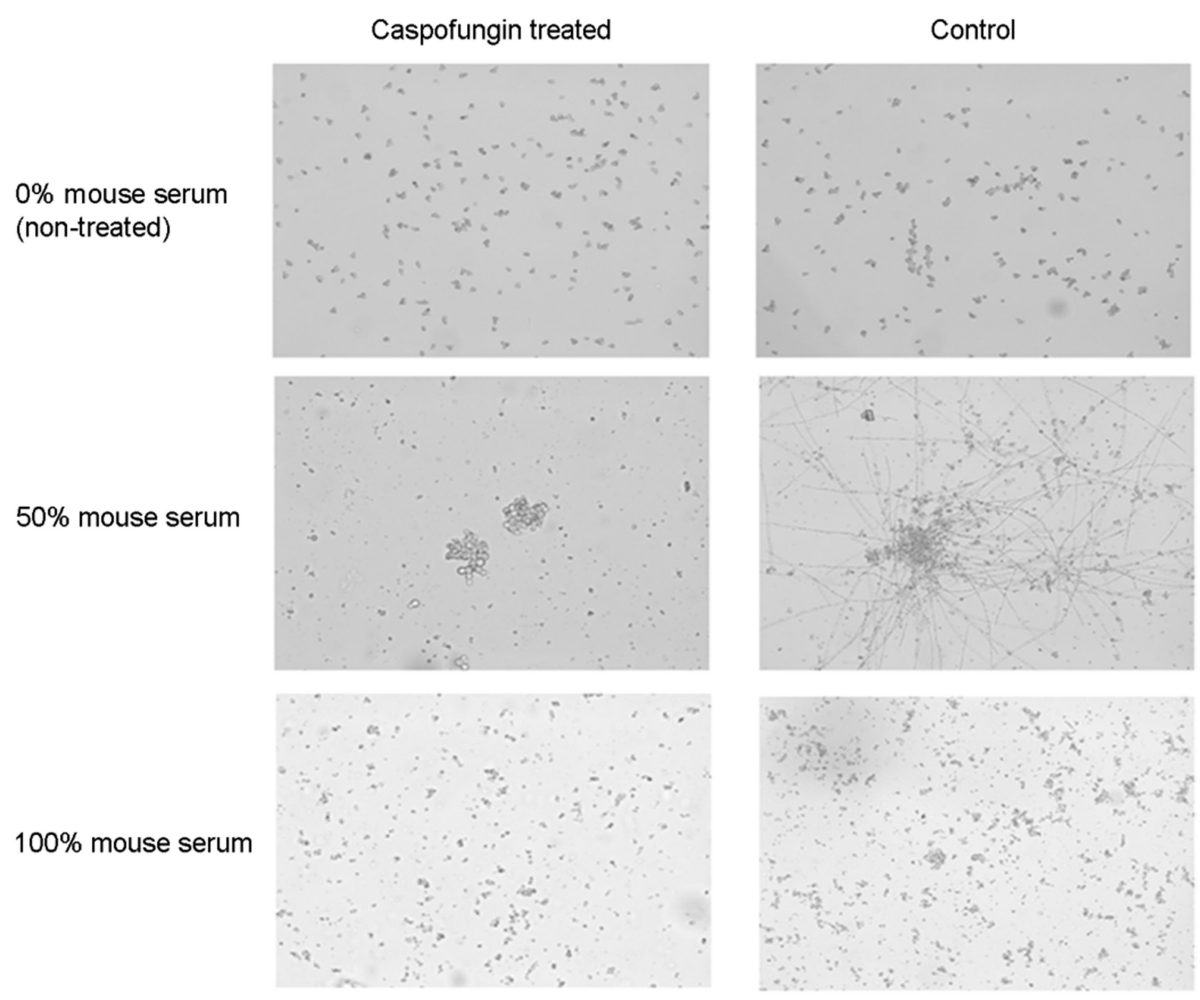

Fig. 3. Morphological changes of C. albicans after caspofungin and mouse serum treatment. 
생육 억제 효과가 뚜렷하게 관찰되어 $\mathrm{MIC}$ 측정을 위해 서는 mouse 혈청이 가장 용이함을 알 수 있었다.

최적의 mouse 혈청 첨가 농도를 분석하기 위해 RPMI 배지에 mouse 혈청의 농도를 $0 \sim 100 \%$ 까지 첨가하여 그 결과를 관찰한 결과, 혈청을 첨가하지 않은 경우, 가성균 사를 거의 형성하지 않았고, 전형적인 원형의 균 형태를 대부분 유지하는 것을 관찰할 수 있었다. 하지만, 혈청을 $10 \%$ 이상 첨가한 경우, 가성균사를 대부분 형성하였으며, 첨가량이 $80 \%$ 이상인 경우, 생장이 감소하면서 대체적으 로 균이 잘 자라지 못하였다(Fig. 2).

Caspofungin $\mathrm{MIC}$ 측정을 위한 최적 혈청 첨가 농도를 분석하기 위해 $0 \%, 50 \%, 100 \%$ 의 mouse 혈청을 caspofungin과 함께 첨가하여 배양한 후 그 결과를 비교해 보 았다. Mouse 혈청을 첨가하지 않았을 경우 $(0 \%$ mouse 혈 청), 균사가 성장하지 못하여 반드시 혈청의 첨가가 필요 함을 알 수 있었고, $50 \%$ 의 mouse 혈청을 첨가한 경우, 균 사가 caspofungin에 대해 가장 잘 반응하는 것을 관찰할 수 있었고, caspofungin을 처리하지 않은 대조군에서도 균 사의 생장상태가 가장 좋았다. Mouse 혈청을 $100 \%$ 첨가 한 경우에는 현미경 관찰 시 배경이 지저분해지는 결과 를 얻을 수 있었다(Fig. 3). 따라서, 배양 시 항진균제와 혈 청 동시 투여조건, 균 접종 양, 혈청 성분과 균사 간의 구분 용이성(현미경 관찰 시 배경), 균체의 생장조건 등 검사에 관한 전체적인 부분들을 고려하였을 때 $50 \%$ 의 mouse 혈청을 첨가한 조건이 caspofungin에 대한 $\mathrm{MIC}$ 측 정 시 최적의 결과를 얻을 수 있음을 확인하였다.

\section{임상분리균주를 이용한 $50 \%$ mouse serum-based caspofungin MIC 측정법의 유용성 평가}

C. albicans 임상분리균주 105 주를 대상으로, 최적화된 $50 \%$ mouse serum-based caspofungin $\mathrm{MIC}$ 측정법의 유용성 을 확인해 보았다. Alamar-modified broth microdilution MIC 측정법을 이용한 caspofungin에 대한 $\mathrm{MIC}_{80}$ 측정치의 범위는 $0.13 \sim 2.0 \mu \mathrm{g} / \mathrm{mL}$ (SD $\pm 0.42 \mu \mathrm{g} / \mathrm{mL}$ )였고, $50 \%$ mouse serum-based $\mathrm{MIC}$ 측정법을 이용한 caspofungin에 대한 $\mathrm{MIC}_{80}$ 측정치의 범위는 $2.0 \sim 32.0 \mu \mathrm{g} / \mathrm{mL}(\mathrm{SD} \pm 9.01 \mu \mathrm{g} /$ $\mathrm{mL}$ )였다. Alamar-modified broth microdilution $\mathrm{MIC}$ 측정법 을 이용한 caspofungin에 대한 $\mathrm{MIC}_{50}$ 측정치의 범위는 $0.13 \sim 2.0 \mu \mathrm{g} / \mathrm{mL}(\mathrm{SD} \pm 0.40 \mu \mathrm{g} / \mathrm{mL})$ 였고, $50 \%$ mouse serumbased $\mathrm{MIC}$ 측정법을 이용한 caspofungin에 대한 $\mathrm{MIC}_{50}$ 측정치의 범위는 $1.0 \sim 16.0 \mu \mathrm{g} / \mathrm{mL}(\mathrm{SD} \pm 2.36 \mu \mathrm{g} / \mathrm{mL}$ )였다 (Table 1).

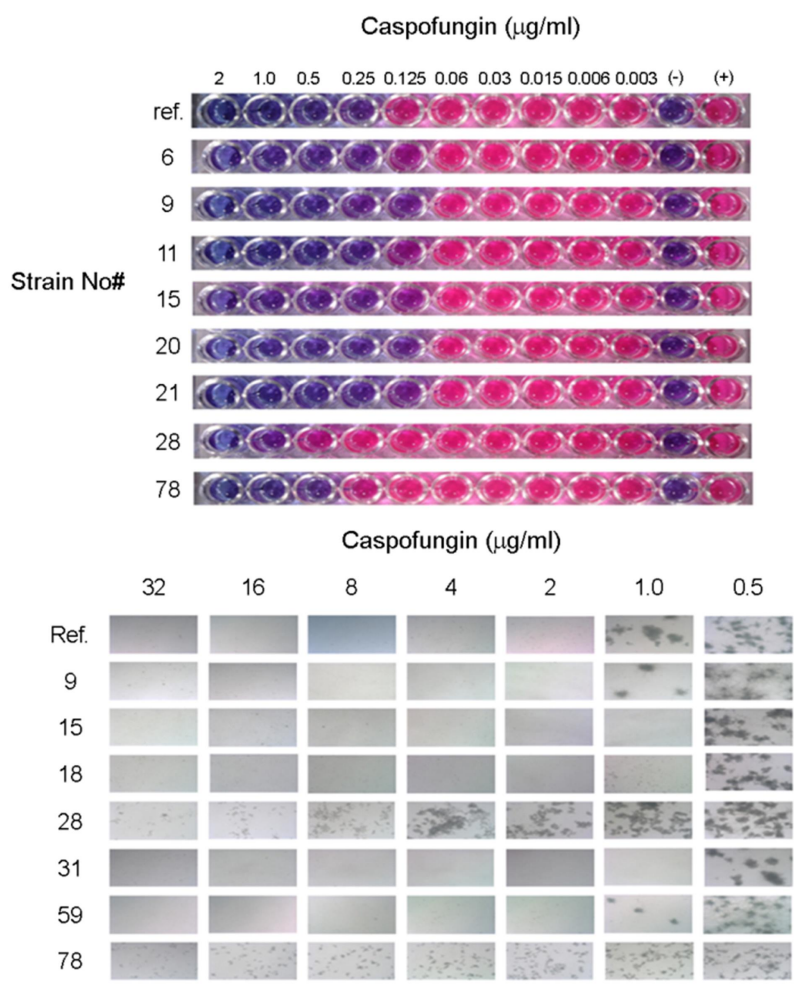

Fig. 4. Comparison of results between Alamar-modified broth microdilution MIC assay and 50\% mouse serum-based MIC assay.

Alamar-modified broth microdilution $\mathrm{MIC}$ 측정법을 이용 한 경우, 총 105 주의 C. albicans 임상분리균주 중 $6,9,11$, $15,20,21$ 균주가 표준균주와 비교해 보다 낮은 $\mathrm{MIC}_{50}$ 을 나타냈다. 50\% mouse serum-based MIC 측정법 시, 총 105 주의 C. albicans 임상분리균주 중 9, $15,16,18,19,24,31$, $42,48,68,87,97$ 균주는 표준균주에 비해 낮은 $\mathrm{MIC}_{50}$ 값 을 나타냈다(Table 1).

Alamar-modified broth microdilution $\mathrm{MIC}$ 측정법과 $50 \%$ mouse serum-based MIC 측정법 간에 caspofungin에 대한 $\mathrm{MIC}_{80}$ 값의 가장 큰 차이를 보인 균주는 28번과 78 번 균 주로서, 28 번 균주의 경우 기존의 $\mathrm{MIC}$ 측정법에서 $\mathrm{MIC}_{80}$ 값이 $2.0 \mu \mathrm{g} / \mathrm{mL}$ 였고, 반면 $50 \%$ mouse serum-based $\mathrm{MIC}$ 측 정법에서 $\mathrm{MIC}_{80}$ 값이 $>32.0 \mu \mathrm{g} / \mathrm{mL}$ 로 약 16 배 이상의 차 이가 있었다. 78 번 균주의 경우, 기존의 $\mathrm{MIC}$ 측정법에서 $\mathrm{MIC}_{80}$ 값이 $0.50 \mu \mathrm{g} / \mathrm{mL}$ 였고, 반면 $50 \%$ mouse serum-based $\mathrm{MIC}$ 측정법에서 $\mathrm{MIC}$ 측정법에서 $\mathrm{MIC}_{80}$ 값이 $32.0 \mu \mathrm{g} /$ $\mathrm{mL}$ 로 약 64배 정도의 차이를 보였다(Table 1, Fig. 4). 
Table 1. MIC results of $C$. albicans reference strain and clinical isolates to caspofungin using by Alamar-modified broth microdilution MIC and 50\% mouse serum-based MIC assays

\begin{tabular}{|c|c|c|c|c|}
\hline \multirow{2}{*}{ Strain no. } & \multicolumn{2}{|c|}{ Alamar-modified broth microdilution MIC assay } & \multicolumn{2}{|c|}{$50 \%$ mouse serum-based MIC assay } \\
\hline & $\mathrm{MIC}_{80}(\mu \mathrm{g} / \mathrm{mL})$ & $\mathrm{MIC}_{50}(\mu \mathrm{g} / \mathrm{mL})$ & $\mathrm{S}^{2} \mathrm{MIC}_{80}(\mu \mathrm{g} / \mathrm{mL})$ & $\mathrm{S}-\mathrm{MIC}_{50}(\mu \mathrm{g} / \mathrm{mL})$ \\
\hline Ref. & 0.25 & 0.25 & 2.0 & 1.5 \\
\hline 1 & 0.50 & 0.50 & - & 2.0 \\
\hline 2 & 0.50 & 0.50 & - & 2.0 \\
\hline 3 & 0.50 & 0.30 & - & 2.0 \\
\hline 4 & 0.50 & 0.50 & - & 2.0 \\
\hline 5 & 0.50 & 0.25 & - & 2.0 \\
\hline 6 & 0.25 & 0.13 & - & 2.0 \\
\hline 7 & 0.50 & 0.30 & - & 2.0 \\
\hline 8 & 0.25 & 0.25 & - & 2.0 \\
\hline 9 & 0.50 & 0.13 & - & 1.0 \\
\hline 10 & 0.50 & 0.50 & - & 2.0 \\
\hline 11 & 0.25 & 0.13 & - & 2.0 \\
\hline 12 & 0.25 & 0.25 & - & 2.0 \\
\hline 13 & 0.50 & 0.50 & - & 2.0 \\
\hline 14 & 0.50 & 0.25 & - & 2.0 \\
\hline 15 & 0.25 & 0.13 & - & 1.0 \\
\hline 16 & 0.50 & 0.25 & - & 1.0 \\
\hline 17 & 0.50 & 0.50 & - & 2.0 \\
\hline 18 & 0.50 & 0.25 & - & 1.0 \\
\hline 19 & 0.25 & 0.25 & - & 1.0 \\
\hline 20 & 0.13 & 0.13 & - & 2.0 \\
\hline 21 & 0.25 & 0.13 & - & 2.0 \\
\hline 22 & 0.50 & 0.25 & - & 2.0 \\
\hline 23 & 0.50 & 0.50 & - & 2.0 \\
\hline 24 & 0.25 & 0.25 & - & 1.0 \\
\hline 25 & 0.25 & 0.25 & - & 2.0 \\
\hline 26 & - & - & 4.0 & 2.0 \\
\hline 27 & 0.25 & 0.25 & - & 2.0 \\
\hline 28 & 2.00 & 1.00 & $>32.0$ & 16.0 \\
\hline 29 & 0.25 & 0.25 & - & 2.0 \\
\hline 30 & - & - & - & 4.0 \\
\hline 31 & - & - & - & 1.0 \\
\hline 32 & - & - & - & 2.0 \\
\hline 33 & - & - & - & 4.0 \\
\hline 34 & 0.50 & 0.50 & - & 2.0 \\
\hline 35 & 1.00 & 0.50 & - & - \\
\hline 36 & 2.00 & 2.00 & - & 2.0 \\
\hline 37 & 0.50 & 0.50 & - & - \\
\hline 38 & 0.50 & 0.25 & - & 2.0 \\
\hline 39 & 0.50 & 0.50 & - & - \\
\hline 40 & 0.50 & 0.50 & 2.0 & - \\
\hline
\end{tabular}


Table 1. MIC results of $C$. albicans reference strain and clinical isolates to caspofungin using by Alamar-modified broth microdilution MIC and 50\% mouse serum-based MIC assays (Continued)

\begin{tabular}{|c|c|c|c|c|}
\hline \multirow{2}{*}{ Strain no. } & \multicolumn{2}{|c|}{ Alamar-modified broth microdilution MIC assay } & \multicolumn{2}{|c|}{$50 \%$ mouse serum-based MIC assay } \\
\hline & $\mathrm{MIC}_{80}(\mu \mathrm{g} / \mathrm{mL})$ & $\mathrm{MIC}_{50}(\mu \mathrm{g} / \mathrm{mL})$ & $\mathrm{S}-\mathrm{MIC}_{80}(\mu \mathrm{g} / \mathrm{mL})$ & $\mathrm{S}-\mathrm{MIC}_{50}(\mu \mathrm{g} / \mathrm{mL})$ \\
\hline 41 & 0.50 & 0.50 & - & 2.0 \\
\hline 42 & 0.50 & 0.50 & - & 1.0 \\
\hline 43 & 1.00 & 1.00 & - & 2.0 \\
\hline 44 & 1.00 & 1.00 & - & - \\
\hline 45 & 1.00 & 0.50 & - & - \\
\hline 46 & 0.50 & 0.50 & - & 2.0 \\
\hline 47 & 1.00 & 1.00 & - & 2.0 \\
\hline 48 & 1.00 & 1.00 & - & 1.0 \\
\hline 49 & 1.00 & 1.00 & - & - \\
\hline 50 & 1.00 & 1.00 & - & 4.0 \\
\hline 51 & 1.00 & 0.50 & - & 4.0 \\
\hline 52 & 1.00 & 1.00 & - & 4.0 \\
\hline 53 & 1.00 & 1.00 & - & 2.0 \\
\hline 54 & 1.00 & 1.00 & - & - \\
\hline 55 & 2.00 & 2.00 & - & 4.0 \\
\hline 56 & 2.00 & 1.00 & - & - \\
\hline 57 & 1.00 & 1.00 & - & 2.0 \\
\hline 58 & 1.00 & 1.00 & - & 2.0 \\
\hline 59 & 1.00 & 1.00 & - & 4.0 \\
\hline 60 & 1.00 & 1.00 & - & 2.0 \\
\hline 61 & 2.00 & 2.00 & 2.0 & - \\
\hline 62 & 1.00 & 1.00 & - & 2.0 \\
\hline 63 & 1.00 & 1.00 & - & 2.0 \\
\hline 64 & 1.00 & 1.00 & - & 2.0 \\
\hline 65 & 1.00 & 1.00 & - & 2.0 \\
\hline 66 & 1.00 & 1.00 & - & 4.0 \\
\hline 67 & 0.50 & 0.50 & - & - \\
\hline 68 & 0.50 & 0.50 & - & 1.0 \\
\hline 69 & 1.00 & 1.00 & - & 2.0 \\
\hline 70 & 1.00 & 1.00 & - & 16.0 \\
\hline 71 & 1.00 & 0.50 & - & 2.0 \\
\hline 72 & 0.50 & 0.50 & - & 2.0 \\
\hline 73 & 1.00 & 0.50 & - & 2.0 \\
\hline 74 & 1.00 & 0.50 & - & 2.0 \\
\hline 75 & 0.50 & 0.50 & - & 2.0 \\
\hline 76 & 0.50 & 0.50 & 2.0 & - \\
\hline 77 & 0.50 & 0.50 & 2.0 & - \\
\hline 78 & 0.50 & 0.50 & 32.0 & - \\
\hline 79 & 0.50 & 0.25 & - & 2.0 \\
\hline 80 & 1.00 & 0.50 & - & 2.0 \\
\hline 81 & 1.00 & 1.00 & - & 8.0 \\
\hline
\end{tabular}


Table 1. MIC results of C. albicans reference strain and clinical isolates to caspofungin using by Alamar-modified broth microdilution MIC and 50\% mouse serum-based MIC assays (Continued)

\begin{tabular}{|c|c|c|c|c|}
\hline \multirow{2}{*}{ Strain no. } & \multicolumn{2}{|c|}{ Alamar-modified broth microdilution MIC assay } & \multicolumn{2}{|c|}{$50 \%$ mouse serum-based MIC assay } \\
\hline & $\mathrm{MIC}_{80}(\mu \mathrm{g} / \mathrm{mL})$ & $\mathrm{MIC}_{50}(\mu \mathrm{g} / \mathrm{mL})$ & $\mathrm{S}-\mathrm{MIC}_{80}(\mu \mathrm{g} / \mathrm{mL})$ & $\mathrm{S}^{-\mathrm{MIC}_{50}}(\mu \mathrm{g} / \mathrm{mL})$ \\
\hline 82 & 0.50 & 0.50 & - & - \\
\hline 83 & 0.50 & 0.50 & - & 8.0 \\
\hline 84 & 0.50 & 0.50 & - & 4.0 \\
\hline 85 & 0.50 & 0.50 & - & 4.0 \\
\hline 86 & 1.00 & 0.50 & - & 2.0 \\
\hline 87 & 1.00 & 0.50 & - & 1.0 \\
\hline 88 & 0.50 & 0.50 & - & 2.0 \\
\hline 89 & 1.00 & 0.50 & - & 4.0 \\
\hline 90 & 1.00 & 1.00 & - & 4.0 \\
\hline 91 & 1.00 & 0.50 & - & 4.0 \\
\hline 92 & 1.00 & 0.50 & - & 4.0 \\
\hline 93 & 0.50 & 0.50 & 2.0 & 2.0 \\
\hline 94 & 0.50 & 0.50 & - & 2.0 \\
\hline 95 & 0.50 & 0.50 & - & 2.0 \\
\hline 96 & 0.50 & 0.50 & - & 2.0 \\
\hline 97 & 0.50 & 0.50 & 2.0 & 1.0 \\
\hline 98 & 0.50 & 0.50 & 2.0 & 2.0 \\
\hline 99 & 2.00 & 2.00 & - & 2.0 \\
\hline 100 & 1.00 & 1.00 & - & 2.0 \\
\hline 101 & 1.00 & 1.00 & - & 2.0 \\
\hline 102 & 1.00 & 1.00 & 2.0 & 2.0 \\
\hline 103 & 1.00 & 1.00 & - & 2.0 \\
\hline 104 & 1.00 & 1.00 & - & 2.0 \\
\hline 105 & 1.00 & 1.00 & - & 2.0 \\
\hline Average & 0.8 & 0.6 & 4.9 & 2.6 \\
\hline $\begin{array}{l}\text { Standard } \\
\text { deviation }\end{array}$ & 0.42 & 0.40 & 9.01 & 2.36 \\
\hline
\end{tabular}

$\mathrm{MIC}_{50}$ : Minimal inhibitory concentration at which $50 \%$ of the strains tested were inhibited

$\mathrm{MIC}_{80}$ : Minimal inhibitory concentration at which $80 \%$ of the strains tested were inhibited

- : unmeasurable

\section{고 찰}

CLSI 가이드라인에 따른 yeast broth microdilution 항진 균제 감수성 검사를 통한 $\mathrm{MIC}$ 측정은 현재 임상에서 사 용 가능한 항진균제 감수성 검사의 기준이 되어 환자의 항진균제 치료 및 임상 연구의 중요한 수단이 되고 있다 (Espinel-Ingroff A et al., 2007). 하지만, 임상에서 항진균제 에 대한 체외 검사와 체내 검사 결과 간의 연관성을 확
인할 수 없다는 제한점이 존재하며, 모든 임상 검사실에 서 표준 검사법을 시행하기에는 복잡하고 불편한 점이 많이 있어 기존 검사에 비해 보다 간편하고 실용적인 방 법에 관한 많은 연구의 필요성이 증가하고 있다(Pfaller MA et al., 1995).

이러한 필요성에 따라 국내·외에서 기존의 표준화된 항진균제 감수성 검사와 macrodilution법, microdilution법 을 비교한 보고가 있었고(Pfaller MA et al., 1994), 산화-환 원 반응에 따른 지시약의 색 변화에 따라 결과를 판독하 
는 비색 분석 검사의 유용성을 입증하기 위한 연구도 있 었다(To WK et al,, 1995). 이 외에도 VITEK-2 시스템과 AST-YS01, ATB FUNGUS 2을 이용해 Candida의 항진균 제 감수성 검사결과를 기존의 표준화된 항진균제 감수성 검사결과와 비교 평가하여 객관적인 결과와 함께 분석 자동화의 기틀을 마련한 연구도 있었다(Park SD et al., 2010). 이러한 연구결과들을 통해 체외 검사결과로는 체 내 검사결과를 정확하게 대변할 수 없음을 알 수 있었다. 최근의 연구에서 Serum-based MIC 측정법이 항진균제의 생체 내 효능을 정확하게 예측 가능하다는 보고가 있었 지만(Odabasi Z et al., 2007), 국내·외에서 이에 대한 임상 평가가 아직 많이 이루어 지지 않았기 때문에 이 측정법 의 정확한 임상적 유용성을 파악하기 위해서는 보다 많 은 임상 연구가 이루어져야 할 것으로 사료된다.

본 연구에서 총 105 주의 C. albicans 임상분리균주를 대 상으로 기존의 표준화된 CLSI 가이드라인에 따른 $\mathrm{MIC}$ 측정법을 변형한 Alamar-modified broth microdilution법과 $50 \%$ mouse serum-based MIC 측정법을 실시하여 caspofungin에 대한 유효성을 분석해 본 결과, 기존 $\mathrm{MIC}$ 측정 법에 비해 $50 \%$ mouse serum-based $\mathrm{MIC}$ 측정법에서 $\mathrm{MIC}$ 비율이 적게는 4배에서 최대 64배까지 증가함을 확인할 수 있었다. 다른 국외의 연구결과에서 RPMI 배지에 $50 \%$ human 혈청을 첨가한 배지를 사용해 Candida spp.에 해 당하는 C. albicans, C.tropicalis, C.glabrata, C. krusei, C. inconspicua, C. parapsolosis, C. orthopsilosis, C. metapsilosis 을 대상으로 casfofungin에 대한 MIC 값을 비교 분석한 결과, $50 \%$ human 혈청을 첨가한 대조군과 첨가하지 않은 대조군 간의 $\mathrm{MIC}$ 비율이 약 $4 \sim 128$ 배의 변화를 보여 본 연구와 유사한 결과를 나타냈다(Foldi R et al., 2012). 이러 한 결과들은 배지 상에서 균주의 배양만을 통해 얻을 수 있는 $\mathrm{MIC}$ 의 측정치가 실제 인체 내에서는 다양한 요인 에 의해 증가될 가능성이 충분히 있음을 시사한다.

또한, Table 1에서 볼 수 있듯이 50\% mouse serum-based $\mathrm{MIC}$ 측정법에서는 균사의 형태학적 모양 관찰을 통해 결과를 해석해야 하기 때문에 대부분의 균주들에서 균주 가 뭉쳐서 자라는 등 정확한 $\mathrm{MIC}_{80}$ 값을 얻기가 힘들었 고, 임상분리균주 간의 표준편차 또한 9.01로 매우 높게 나타났다. 하지만, 대부분의 균주들에서 $\mathrm{MIC}_{50}$ 값을 구하 기에 용이하였기 때문에 $50 \%$ mouse serum-based MIC 측 정법을 이용할 경우 $\mathrm{MIC}_{50}$ 값을 활용하는 것이 보다 정 확한 결과치를 얻기에 유리할 것으로 사료된다.

결론적으로, 항진균제에 대한 C. albicans 임상분리균주
의 정확한 $\mathrm{MIC}$ 측정을 위해서는 첨가한 혈청의 종류와 양, 항진균제의 종류, Candida 종 간의 특성 등에 대한 충 분한 고려가 필요할 것으로 사료된다. 특히 caspofungin에 대한 C. albicans 임상분리 균주의 $\mathrm{MIC}$ 측정 시, in vivo 상의 $\mathrm{MIC}$ 측정치를 최대한 구현해 내기 위해서는 혈청 첨가를 통한 $\mathrm{MIC}$ 측정법의 수행이 필수적일 것으로 사 료된다.

\section{Conflict of interest}

The authors have no financial conflicts of interest.

\section{REFERENCES}

Espinel-Ingroff A, Fothergill A, Ghannoum M, Manavathu E, Ostrosky-Zeichner L, Pfaller MA, Rinaldi MG, Schell W, Walsh TJ. Quality control and reference guidelines for CLSI broth microdilution method (M38-A document) for susceptibility testing of anidulafungin against molds. J Clin Microbiol. 2007. 45: 2180-2182.

Foldi R, Szilagyi J, Kardos G, Berenyi R, Kovacs R, Majoros L. Effect of $50 \%$ human serum on the killing activity of micafungin against eight Candida species using time-kill methodology. Diagn Microbiol Infect Dis. 2012. 73: 338-342.

Healy CM, Baker CJ, Zaccaria E, Campbell JR. Impact of fluconazole prophylaxis on incidence and outcome of invasive candidasis in a neonatal intensive care unit. J Pediatr. 2005. 147: 166-171.

Kanafani ZA, Perfect JR. Antimicrobial resistance: resistance to antifungal agents: mechanisms and clinical impact. Clin Infect Dis. 2008. 46: 120-128.

Odabasi Z, Paetznick V, Rex JH, Ostrosky-Zeichner L. Effects of serum on in vitro susceptibility testing of echomocandins. Antimicrob Agents Chemother. 2007. 51: 4214-4216.

Park SD, Uh Y, Jang IH, Yoon KJ, Shin JH. Comparison of ATB FUNGUS 2 and VITEK-2 antifungal susceptibility (ASTYS01) tests for Candida species isolated from blood culture. Korean J Clin Microbiol. 2010. 13: 114-120.

Pfaller MA, Grant C, Morthland V, Rhine Chalberg J. Comparative evaluation of alternative methods for broth dilution susceptibility testing of fluconazole against Candida albicans. J Clin Microbiol. 1994. 32: 506-509.

Pfaller MA, Messer SA, Coffmann S. Comparison of visual and spectrophotometric methods of MIC endpoint determinations by using microdilution methods to test five antifungal agents, 
including the new triazole. J Clin Microbial. 1995. 33: 1094 -1097 .

Pfaller MA. Nosocomial candidiasis: emerging species, reservoirs and modes of transmission. Clin Infect Dis. 1996. 22: 89-94.

Pfaller MA, Rex JH, Rinaldi MG. Antifungal susceptibility testing: technical advances and potential clinical applications. Clin Infect Dis. 1997. 24: 766-784.

Rex JH, Pfaller MA, Walsh TJ, Chaturvedi V, Espinel-Ingroff A, Ghannoum MA, Gosey LL, Odds FC, Rinaldi MG, Sheehan DJ, Warnock DW. Antifungal susceptibility testing: practical aspects and current challenges. Clin Microbial Rev. 2001. 14: 643-658.

Rex JH, Alexander BD, Andes D, Arthington-Skaggs B, Brown SD, Chaturvedi V, Ghannoum MA, Espinel-Igroff A, Knapp CC, Ostrosky-Zeichner L, Pfaller MA, Sheehan DJ, Walsh TJ. Reference method for broth dilution antifungal susceptibility testing of yeasts. CLSI. 2008.

Shin JH, Lim WH, Shin DH, Suh SP, Ryang DW. Candida species isolated from clinical specimens and medical personnel. Korean J Infect Dis. 1999. 31: 481-486.

Tiballi RN, He X, Zarins LT, Revankar SG, Kauffman CA. Use of a colorimetric system for yeast susceptibility testing. J Clin Microbio. 1995. 33: 915-917.

To WK, Fothergill AW, Rinaldi MG. Comparative evaluation of macrodilution and Alamar colormetric microdilution broth methods for antifungal susceptibility testing of yeast isolates. J Clin Microbiol. 1995. 33: 2660-2664.

Walsh TJ, Teppler H, Donowitz GR, Maertens JA, Baden LR, Dmoszynska A, Cornely OA, Bourque MR, Lupinacci RJ, Sable CA, dePauw BE. Caspofungin versus liposomal amphotericin B for empirical antifungal therapy in patients with persistent fever and neutropenia. N Engl J Med. 2004. 351: 1391-1402.

White TC, Marr KA, Bowden RA. Clinical, cellular, and molecular factors that contribute to antifungal drug resistance. Clin Microbial Rev. 1998. 11: 382-402. 